\title{
Technology and Innovation in Israel: Advancing Competitive Position in a Global Environment
}

\author{
Yaron Katz \\ HIT_Holon Institute of Technology, Holon, Israel \\ Email: yaron@ykatz.com
}

How to cite this paper: Katz, Y. (2018). Technology and Innovation in Israel: Advancing Competitive Position in a Global Environment. Open Journal of Political Science, 8, 536-546. https://doi.org/10.4236/ojps.2018.84033

Received: August 13, 2018

Accepted: October 28, 2018

Published: October 31, 2018

Copyright $\odot 2018$ by author and Scientific Research Publishing Inc. This work is licensed under the Creative Commons Attribution International License (CC BY 4.0).

http://creativecommons.org/licenses/by/4.0/

(c) (i) Open Access

\begin{abstract}
The question that stands at the heart of this research is, based on the Israeli experience: how technology is changing society? Such question is extremely important, as countries seek to advance in their competitive position in a global environment. The assumption made here is that competition between countries has accelerated with the development of technology, as the distinction between developed and developing countries became apparent. That brings up the question: what is needed to build comparative advantages and be successful in a global world? Israel is a remarkable example of global competition, as high-tech development has been based on the performance of the country in the field of innovation. However, as the research demonstrates, the contradiction in Israel's status is evident in the supremacy of the country in technological advancement and the weaknesses in social-economic development. This proves the dilemma countries face in advancing technology: while it is obvious that both technology and globalization have a great and positive impact around the world, they have been negative for the socio-economic gaps and inequality. This is where the role of developing countries is apparent in establishing a successful high-tech industry and a growing global economy, despite social disadvantages.
\end{abstract}

\section{Keywords}

Technology, Society, Innovation, Inequality, Israel

\section{Introduction}

Researchers have tried to define the concept of technology. Yet, it is not easy to find a perfect definition that considers all the aspects of this complex issue. As a general definition, we can say that technology consists of two primary components: a physical component which comprises of items such as products, tooling, 
equipment, blueprints, techniques, and processes; and the informational component which consists of know-how in management, marketing, production, quality control, reliability, skilled labor and functional areas (Kumar, Kumar,, \& Persaud, 1999). Although much of today's coverage on technology is focused on whether technological advancements are good or bad for the world we live in today (Bremner, 2016), technology and human life cannot be separated, and society has a cyclical co-dependence on technology (Ramey, 2012). As explained by Klaus Schwab, Founder and Executive Chairman, World Economic Forum in Davos Switzerland, in the 2016 Forum, where the overarching theme was the disruptive nature of technology: "We must develop a comprehensive and globally shared view of how technology is affecting our lives and reshaping our economic, social, cultural, and human environments. There has never been a time of greater promise, or greater peril" (Hutt, 2016).

The effects of technological change are creating immense transformations in the way companies and nations organize production, trade goods, invest capital, and develop new products and processes (Muroyama \& Guyford, 1988). In examining the impact of technology on our lives, there is no doubt that the information age led to a revolution in how we communicate and receive information (Castells, 2014). Technology plays a large role in globalization on a cultural, political and economic level (Mazzucato, 2015). It has become a fundamental vehicle for the development of every country, in areas such as the economy, politics, military and even education. We live in a world of technology, which is improving at such a rapid rate, that we barely have time to learn the old technology before new technology comes out. This changes many things including how we interact and how we receive information, and leads to questions of how our culture can adapt to such change and what affect it will have on the future. The question therefore becomes, do we influence technology, or does technology influence us?

The main issue under debate when it comes to technology and society is how to examine the state of each country in terms of technological advancement and global competition. A developed country has a growing economy and advanced technological infrastructure, while a developing country is one that is seeking to become more advanced economically and technologically (Staff, 2015). This calcification is required to examine the competitive global status of countries (Surbhi, 2015), emphasizing the differences in technological advancement between developed countries, developing countries and third world countries (Porter, 1990).

\section{The Global Advantage of Technology}

Israel is a prime example of the domination of technology over society. The country's development is a product of the digital revolution and major socio-cultural and economic changes, which situate Israel as a developed country in terms of technology, however one which falls behind many countries in major 
social and policy issues, to what this research defines as the digital gap.

Israel is an interesting case among industrialized countries as the level of inequality is high across a number of measures (Staff, 2015). The country is divided along ethnic, national, religious, and political lines, producing unique conditions within which the effects of factors such as gender, class, region, age, and education are highly contextualized. Income inequality in Israel is among the highest in the Western world; the poverty rate and income gap between classes are similarly high (Keeley, 2015). According to OECD report, Israel is second only to the United States among developed nations in inequality (OECD, 2011). Another OECD report which examined income inequality and the gap between the richer and the poorer segments of society in member states, found that Israel is ranked in $1^{\text {st }}$ place with the highest percentage of people living below the poverty line. It is also ranked 3rd in Income Inequality (OECD, 2016). This gap creates an interesting situation fueled by social contrasts: a developed country in terms of technology and a developing society, or, in other words, a developed and successful economy with high rates of poverty.

The question that stands at the heart of this research is, based on the Israeli experience: how technology is changing society? In order to examine this, the research is looking at the impact of technological advancement in the development of technology while examining the way Israel has developed to a "Start-Up Nation" (Senor \& Singer, 2009), with the largest number of start-up companies globally, second only to the USA (Bahar, 2016). The country is leading in high-tech worldwide (Reuben, 2014). It is a leading community for start-ups, entrepreneurs, investors, venture capitalists, angels, developers, researchers and recruiters, and a world leader in terms of research and development spending as a high percentage of the economy (Senor \& Singer, 2009). After the US and China, Israel has most companies listed on the NASDAQ stock exchange (McKenna, 2017). Israel ranks third in the World Economic Forum's ranking of most innovative economies and its startups receive nearly $20 \%$ of global private investment in cyber-security (Israelidag, 2017).

In addition to technology advancement and global competitiveness, another major factor in a developed country is a secured economy, and the development of technology has indeed elevated the Israeli economy. The technological advantage of Israel has promoted its economy, which has grown as a result more rapidly than most other advanced economies. Israel is leading global competition, as high-tech development has been based on leadership in innovation (OECD, 2018). The country has a highly developed technology sector. It produces more start-up companies than large, peaceful, and stable nations like Japan, China, India, Korea, Canada, and the United Kingdom. It has the highest density of tech start-ups in the world and they attract more venture capital dollars per person than any country-2.5 times the U.S., 30 times Europe, 80 times India, and 300 times China (Senor \& Singer, 2009). Israel's venture capital industry is one of the biggest outside the USA and the research centers of foreign 
multinationals are investing a considerable amount of venture capital in the Israeli economy (UNESCO Science Report, 2015).

Innovation led to new products and more-efficient production methods, with dramatic changes in the way nations and economies are organized and managed, highlighting the connections between new ideas and methods and the organizational structure needed to implement them (Bernanke, 2011). Innovation is a major driver of productivity, economic growth and development, and the Israeli government made a strategic decision to promote technology by providing financial support for commercial R \& D (Moss, 2011). According to the Israel Innovation Authority (2018), innovation is by far the most valuable resource for the State of Israel, serving as a national asset crucial to economic prosperity, and strengthening the innovation ecosystem would further develop and support technological innovation in Israel. This shows the impact of technology on the economy and society, which is apparent in Israel, since in a world of increasingly global competition, nations have become more important, as national prosperity is created, not inherited (Porter, 1990).

The leadership of Israel in technology demonstrates the importance of technological advancement in global competition and the way technology can promote countries and economies. As determined by the Israel Innovation Authority, maintaining Israel's position at the forefront of global innovation will elevate the entire economy through technological innovation, as Israel enjoys a vibrant entrepreneurial culture, strong technological infrastructure and highly skilled human capital, allowing it to grow on the basis of innovation. This impressive performance reflects the dominance of the high-tech sector, which constitutes the country's main growth engine and contributes $46 \%$ of Israeli exports (UNESCO Science Report, 2015).

The combination of structural reforms and huge investments in R \& D led to Israel's high-tech boom (Economist, 2010), and its technological leadership is based on global competitiveness. It is ranked in the top 20 nations in the world on the UN's Human Development Index, which places it in the category of "Very Highly Developed". According to OECD (2018) Economic Surveys, with the benefit of technology, the economy continues to register remarkable macroeconomic and fiscal performance. Growth is strong and unemployment is low. The external surplus is comfortable, and the public debt-to-GDP ratio, already well below the OECD average, is still falling. According to former Governor of the Bank of Israel, Karnit Flug, the country is a leading community for start-ups and a world leader in terms of research and development spending as a percentage of the economy. It has a highly developed technology sector and the largest share of early-stage and seed venture capital funding in GDP among OECD countries (Flug, 2017).

\section{The Social-Cultural Aspects of Technology}

While looking at the social and cultural aspects of technology, the paper ex- 
amines the way Israel accomplished a highly developed technology sector, proving that technology is a key driver of change. The process was gradual but consistent. Over the past three decades, Israel experienced an economic turnaround unprecedented in character and scope. The country passed from the industrial society to the high-tech society and global companies established themselves in Israel, increasing the economy size and creating a global and powerful nation (Aharoni, 2013). In a matter of years, Israel has significantly transformed from a long established and monopolistic system to a more highly developed, sophisticated, and global approach (Kaplan, 2015), experiencing an economic turnaround unprecedented in character and scope (Economist, 2010). The change began in transforming from a closed and concentrated economy with a large public sector and burdensome tax regime, to an open and competitive economy that attracts foreign investments and participates in global financial markets (Kaplan, 2015a). Simultaneously, it shifted its economic center of gravity from labor-intensive industrial production to a knowledge-based economy focused on the development of technological innovation. The country passed from industrial society to high-tech society and significantly transformed from a long established and monopolistic system to a more highly developed, sophisticated and global approach (Economist, 2010).

The Israeli economy is driven by industries based on electronics, computers and communication technologies, the result of investment in defense infrastructure. Israeli defense industries have traditionally focused on electronics, avionics and related systems, and the development of these systems has given high-tech industries a qualitative edge in civilian spin-offs in the software, communications and Internet sectors (UNESCO Science Report, 2015). The growth of the high tech industry has been enormous: in the 20 -year period of 1997-2017, 16,000 high-tech companies were set up, of which 8000 are currently active. The nation has 505 cyber security companies, which have raised some $\$ 5.6$ billion, and 1487 life sciences companies that have raised $\$ 13.5$ billion. Israeli venture capital funds raised about $\$ 20$ billion in 1997-2017; the industry has some 1800 female high-tech entrepreneurs, of which 490 are active CEOs and entrepreneurs; there are 365 currently active foreign R \& D centers in Israel; and there are 356 currently active Israeli incubators and accelerators (IVC Research Center, 2018). Israel tops the world for R \& D intensity, reflecting the importance of research and innovation for the economy (UNESCO Science Report, 2015).

According to Economic Survey of Israel (2018), the Israeli economy has grown faster and more consistently than nearly any other in the OECD for the past 15 years. With the benefit of the development of the technology, the Israeli economy is enjoying its 15th consecutive year of growth-equivalent to the period of high-tech boom (Ackerman, 2018). Today Israel operates in a global market and is able to focus on expanding globally, leading the world in scientific research and technology (Economist, 2010). According to the World Economic 
Forum (2018), Israel is the 25th-strongest economy in the world. In 2015, it was ranked $5^{\text {th }}$ in most innovative countries, ahead of US and UK, according to the Bloomberg Innovation Index, an annual ranking of countries that measures performance in research and development, tech education, patents, and other marks of technology prowess (Coy, 2015). In 2017 and 2018 Israel was ranked $10^{\text {th }}$ (Jamrisko \& Lu, 2018). According to the Ministry of Foreign Affairs (2016), Israel is an industrialized country with most of its manufacturing, including many traditional fields, based on intensive and sophisticated research \& development and hi-tech. Technology is pushing the economy, and the fastest growth rates, averaging 8 percent annually, are in hi-tech, with almost $80 \%$ of hi-tech products being exported. The supremacy of technology gives Israel a global leadership, as it attracts about $15 \%$ of the world's venture-capital investment in cyber-security. The quality of Israel's R \& D is ranked according to U.N. among the first 10 in the world. In terms of the human development index (HDI) in Israel, which is the index used by the United Nations to measure the progress of a country, was 0.899 points in 2015, leaving it in 19th place in the table of 188 countries published.

The high global standing of Israel shows the supremacy of technology and its important role in the development of the economy. Israel advanced economic development and competitiveness on a global level and uses economic planning to maintain global economic competitiveness. However, although it has a strong economy and the income inequality has decreased, there are still financial gaps and lack of social unity, according to the OECD (2018). Still, there is way to go to, as Israel's economy performs well both in terms of macroeconomic and fiscal outcomes and is very successful, but there are some key problems which act as impediments to the country's future economic and social development (Carngie Moscow Center, 2015).

As the research demonstrates, the growth of the technology sector has been counter to the social difficulties and the prosperity of the country is based on the success of technology causes a major social gap. Although Israel has in the last 20 years achieved impressive economic results, this growth has been accompanied by a disturbing transformation in the country's income distribution and society, as alongside the dramatic growth in the economy, Israel has experienced a dramatic widening of income disparities. Key measures of inequality have soared, and the extreme inequality has a corrosive effect on social and political life (Krugman, 2015). The percentage of Israelis living under the poverty line was higher in 2016 (18.6\%) than in 2000 (17\%) (Sover-Heruti, 2018). As a result, Israel has one of the highest levels of income inequality in the world, despite a slight improvement that has taken place in the past few years. 21 percent of Israelis live below the poverty line, making Israel country with the highest percentage in the west (Poch, 2016).

Despite the social gaps, the advantages of technology are praised byglobal policymakers and researches, proving the way technology is leading global compe- 
tition. Israel is the fifth most unequal OECD country, although the OECD found the country ranks among the best for life satisfaction, health status and educational achievements (Hodgson, 2017). According to the World Economic Forum, Israel is the 25th-strongest economy in the world (Bar-Tal \& Klein, 2018). According to the World Bank (2016), a developed country requires that the economic structure would be secured and standards of living must be maintained, and the secured and globalized structure of the Israeli economy is maintained by the leading rating agencies. Standard \& Poor's credit rating for Israel stands at AA-with stable outlook-citing Israel's exceptionally strong economic performance and stable economic outlook. The AA-rating from S \& $\mathrm{P}$ is the highest rating Israel has ever received from the credit agency. There are 17 countries that share the prestigious AA rating (Milman, 2018). Moody's credit rating for Israel is A1 with positive outlook. Fitch's credit rating is A+ with stable outlook (Klein, 2018).

The advantages of technology are also praised by Israeli policymakers and researches, which claim that social issues can be dealt best with free market and technological advancement. According to the Israeli Institute for Economic Planning (IEP), the government's role in a free economy should focus on creating infrastructure for innovation and economic growth, improving access to education and business opportunities and handling market failures that limit competition. Former Governor of the Bank of Israel, Karnit Flug, says that the Israeli economy is an open economy that is greatly influenced by developments abroad, which is reflected in growth rates in the economy, which are very much connected to those around the world. The influence of activity abroad is mainly reflected in global trade, which affects demand for Israeli exports, both in goods and in services (Flug, 2014). In a meeting of the Knesset Interior Committee which approved the reform in business licensing, Netanyahu added: "I received IMF data according to which Israel has surpassed the average per capita income and the reason is because we have led a free economy here. If we did not do this we would be in a completely different situation. We have turned Israel into a free economy and thus everything has begun to flourish" (Israel Ministry of Foreign Affairs, 2018).

\section{Conclusion}

The research examines the impact of technology over society as it is evident in Israel-a country which is considered a "Start-Up Nation" on the one hand and a developing country on the other. Research of Israel is important to understand the impact of technology over society, because in the specific case of Israel, gaps are predominating among society. In terms of technology, Israel is very powerful with a technologically advanced market economy with cut diamonds, high-technology equipment and pharmaceuticals among its major exports. The country is highly developed in terms of life expectancy, education, per capita income and other human development index indicators. But it also has one of the most unequal 
economies in the Western world, with significant gaps between the rich and poor. Inequalities have declined in recent years, mainly among Israeli-Arabs and the Ultra-Orthodox, but poverty remains widespread, particularly among these disadvantaged groups-creating the major digital gap that identifies Israel.

The research examines the impact of technology on society by looking at the impact of technology on Israeli society. The main issue that this research investigates is how we label Israel-a developed country and a leading start-up nation which falls behind many countries in major social and policy categories. As determined by the research, the gap grows as the country becomes more dependent on technology in both its economic and democratic institutions. Israel is a perfect example of this contradiction, since it is a high-tech nation, which stands in the front of global media changes. The use of technology is widespread and Israelis are leading consumers of new media. Israeli society is widely connected to global policy, and the political developments are widely covered in the global media. Israeli society is, however, marked by a lack of social cohesion and significant disparities, which penalizes parts of the population and threatens the longer-term sustainability of these good results.

\section{Conflicts of Interest}

The authors declare no conflicts of interest regarding the publication of this paper.

\section{References}

Ackerman, G. (2018). Behind Israel's High-Tech Reputation Is a Low-Tech Economy. Bloomberg.

https://www.bloomberg.com/news/articles/2018-02-14/israel-s-low-tech-economy-beli es-reputation-as-global-tech-hub

Aharoni, Y. (2013). The Israeli Economy: Dreams and Realities. Abingdon: Routledge.

Bahar, D. (2016). Delivering on Economic Prosperity in Israel: How Monopolies Are Hampering the Startup Nation. Brooking.

https://www.brookings.edu/blog/markaz/2016/05/04/delivering-on-economic-prosperi ty-in-israel-how-monopolies-are-hampering-the-start-up-nation/

Bar-Tal, E., \& Klein, Z. (2018). Israel Is the 25th-Strongest Economy in the World. New Index Finds, Israel Hayom.

http://www.israelhayom.com/2018/01/24/israel-is-the-25th-strongest-economy-in-theworld-new-index-finds/

Bernanke, S. B. (2011). Promoting Research and Development: The Government's Role, at the Conference on "New Building Blocks for Jobs and Economic Growth". Washington DC.

https://www.federalreserve.gov/newsevents/speech/bernanke20110516a.htm

Bremner, I. (2016). These 5 Facts Explain How Technology Is Shaping Our World. Time. http://time.com/4187146/davos-2016-technology-facts/

Carngie Moscow Center (2015). Israeli Economy and Global Challenges: Situational Analysis in the Context of World and Regional Problems.

http://carnegie.ru/2015/11/27/israeli-economy-and-global-challenges-situational-analy sis-in-context-of-world-and-regional-problems-event-5105 
Castells, M. (2014). The Impact of the Internet on Society: A Global Perspective. https://www.technologyreview.com/s/530566/the-impact-of-the-internet-on-society-aglobal-perspective/

Coy, P. (2015). The Bloomberg Innovation Index. https://www.bloomberg.com/graphics/2015-innovative-countries/

Economic Survey of Israel (2018). http://www.oecd.org/israel/economic-survey-israel.htm

Economist, T. (2010). Beyond the Start-Up Nation. http://www.economist.com/node/17796932?story_id=17796932

Flug, K. (2014). Strengths and Challenges Facing the Israeli Economy: Main Points of Remarks by Dr Karnit Flug, Governor of the Bank of Israel, at the Jerusalem UItra-Orthodox Campus of Ono Academic College. https://www.bis.org/review/r141208j.htm

Flug, K. (2017). Two Economies-One Society. Remarks by Karnit Flug, Governor of the Bank of Israel, at the Eli Hurvitz Conference on Economy and Society "One Society-One Economy". https://www.bis.org/review/r170728f.htm

Muroyama, J. H., \& Guyford, H. (eds.) (1988) Description, Globalization of Technology: International Perspectives. Chapter: Overview, The National Academies Press and the Transportation Research Board. https://www.nap.edu/read/1101/chapter/2

Hodgson, C. (2017). The 8 Most Unequal Major Economies in the World. Business Insider UK.

http://uk.businessinsider.com/the-8-major-economies-with-most-inequality-2017-8

Hutt, R. (2016). 9 Quotes That Sum up the Fourth Industrial Revolution. World Economic Forum, 23 January.

https://www.weforum.org/agenda/2016/01/9-quotes-that-sum-up-the-fourth-industrial -revolution/

Israel Innovation Authority (2018). http://www.matimop.org.il/about_authority.html

Israel Ministry of Foreign Affairs (2018).

http://www.mfa.gov.il/MFA/AboutIsrael/Economy/Pages/ECONOMY-\%20Sectors\%20 of $\% 20$ the $\% 20$ Economy.aspx

Israelidag (2017). Netanyahu $i$ The Economist: The World in 2018. November 30, 2017. http://israelidag.se/netanyahu-i-the-economist-the-world-in-2018/

IVC Research Center (2018). http://www.ivc-online.com/

Jamrisko, M., \& Lu, W. (2018). The U.S. Drops Out of the Top 10 in Innovation Ranking. January 23, 2018.

https://www.bloomberg.com/news/articles/2018-01-22/south-korea-tops-global-innova tion-ranking-again-as-u-s-falls

Kaplan, J. (2015). Introduction: The Diversity of Israeli Society. The Jewish Agency. http://www.jewishagency.org/society-and-politics/content/36171

Kaplan, J. (2015a). Ethnicity and the Socio-Economic Gap in Israel. The Jewish Agency. http://www.jewishagency.org/society-and-politics/content/36576/

Keeley, B. (2015). Income Inequality, the Gap between Rich and Poor. OECD, December 15, 2015.

https://www.oecd-ilibrary.org/social-issues-migration-health/income-inequality_97892 $64246010 \mathrm{en}$

Klein, Z. (2018). Moody’s Affirms Israel's A1 Credit Rating. Israel Hayom, July 23, 2018. https://jewishwebsite.com/featured/moodys-affirms-israels-a1-credit-rating-gives- $\% \mathrm{E} 2$ $\% 80 \% 8$ Eeconomy-positive-outlook/31814/ 
Krugman, P. (2015). Israel's Gilded Age. The New York Times, March 16, 2015.

https://www.nytimes.com/2015/03/16/opinion/paul-krugman-israels-gilded-age.html? $\underline{\mathrm{hp} \& a c t i o n}=$ click\&pgtype $=$ Homepage\&module $=\mathrm{c}$-column-top-span-region\&region $=\mathrm{c}-$ column-top-span-region \&WT.nav=c-column-top-span-region

Kumar, V., Kumar, U., \& Persaud, A. (1999). Building Technological Capability through Importing Technology: The Case of Indonesian Manufacturing Industry. Journal of Technology Transfer, 24, 81-96. https://doi.org/10.1023/A:1007728921126

Mazzucato, M. (2015). What Is Government's Role in Sparking Innovation? World Economic Forum, 17 April 2015.

https://www.weforum.org/agenda/2015/04/what-is-governments-role-in-sparking-inn ovation/

McKenna, J. (2017). Israel Is a Tech Titan. These 5 Charts Explain Its Startup Success. World Economic Forum, 19 May 2017.

https://www.weforum.org/agenda/2017/05/tiny-israel-is-a-tech-titan-these-5-charts-ex plain-its-startup-success/

Milman, O. (2018). S \& P Raises Israel's Credit Rating to Record-AA. Ynet, April 8, 2018. https://www.ynetnews.com/articles/0,7340,L-5322531,00.html

Moss, I. (2011). Start-Up Nation: An Innovation Story. OECD Observer No. 285, Q2 2011.

http://oecdobserver.org/news/fullstory.php/aid/3546/Start-up_nation:_An_innovation _story.html

OECD (2011). An Overview from Growing Income Inequalities in OECD Countries: Main Findings. https://www.oecd.org/els/soc/49499779.pdf

OECD (2016). OECD Economic Survey on Israel.

http://www.oecd.org/eco/surveys/Israel-2018-OECD-economic-survey-overview.pdf

OECD (2018). OECD Economic Surveys: Israel.

https://www.oecd-ilibrary.org/economics/oecd-economic-surveys-israel-2018/inequalit y-and-poverty-remain-high_eco_surveys-isr-2018-graph5-en

Poch (2016). Israel Has Third Highest Gap between Rich and Poor in the World. Iseael Post, January 13. https://www.israelnationalnews.com/News/News.aspx/206392

Porter, M. E. (1990). The Competitive Advantage of Nations. Harvard Business Review. https://hbr.org/1990/03/the-competitive-advantage-of-nation

Ramey, K. (2012). Technology and Society_Impact of Technology on Society. November 12, 2012, Useoftechnology.com.

https://www.useoftechnology.com/technology-society-impact-technology-society/

Reuben, R. S. C. (2014). Imagine a World without Israel-Part 2. Huffington Post. http://www.huffingtonpost.com/rabbi-steven-carr-reuben-phd/imagine-a-world-witho ut-i_1_b_5706935.html

Senor and Singer (2009). Start-Up Nation: The Story of Israel's Economic Miracle. Hachette Group Us.

Sover-Heruti, T. (2018). Study Shows Severe Household Income Inequality in Israel on the Rise. Haharetz, January 24, 2018.

https://www.haaretz.com/israel-news/business/study-shows-israeli-household-incomeinequality-on-the-rise-1.5762992

Staff, T. (2015). Developed Economy. http://www.investopedia.com/terms/d/developed-economy.asp

Surbhi, S. (2015). Financial Times, June 18, 2015: Difference between Developed Countries and Developing Countries. 
https://keydifferences.com/difference-between-developed-countries-and-developing-co untries.html

UNESCO Science Report (2015). Towards 2030.

http://unesdoc.unesco.org/images/0023/002354/235406e.pdf

World Bank (2016). Somalia Overview.

http://www.worldbank.org/en/country/somalia/overview 